\title{
High cell density growth of High Five suspension cells in DO-controlled wave-mixed bioreactors
}

\author{
Teddy Beltrametti ${ }^{1}$, Nicole C Bögli ${ }^{1 *}$, Gerhard Greller ${ }^{2}$, Regine Eibl ${ }^{1}$, Dieter Eibl ${ }^{1}$ \\ From 22nd European Society for Animal Cell Technology (ESACT) Meeting on Cell Based Technologies \\ Vienna, Austria. 15-18 May 2011
}

Insect cells such as High Five cells used in the manufacture of biopharmaceuticals are best grown in wavemixed bioreactors (1). This is due to the continual blending of foam with the culture medium which results from the wave-induced mixing and permanent renewal of the medium surface. Even the addition of an antifoam agent is not required.

Process conditions which ensure maximum High Five cell densities and which have been reported to be about $8 \times 10^{6}$ cells $\times \mathrm{mL}^{-1}(2)$ were determined in Biostat CultiBag RM50 optical experiments for batch mode and $1 \mathrm{~L}$ culture volume. Seed inoculum for these experiments was generated in single-use shake flasks (Corning) incubated in an Infors 'Multitron shaker $\left(27^{\circ} \mathrm{C}, 100 \mathrm{rpm}, 25\right.$ $\mathrm{mm}$ shaking diameter). Biostat CultiBag RM50 optical was controlled in four different modes: non-pH- and non-DO-controlled, DO- controlled, pH-controlled, DO- as well as pH-controlled. The DO level was guaranteed by increasing the rocking rate up to $28 \mathrm{rpm}$ and, if required by addition of pure oxygen. In process control was supplemented with off-line analyses of cell density, viability, metabolites (glucose, glutamine, glutamate, lactate, ammonium) and $\mathrm{pH}$.

While the influence of the type of bioreactor's control on the maximum growth rate $\left(0.041-0.044 \mathrm{~h}^{-1}\right)$ and doubling time (15.6-17.7 h) was negligible, maximum cell densities were achieved with DO regulation (set point $50 \%$ ). Maximum cell densities ranged between 8.2 and 9.4 $\times 10^{6}$ cells $\mathrm{x} \mathrm{mL} \mathrm{m}^{-1}$ and represent the highest values described for High Five cells so far in the literature. They are 35\% higher compared to those seen in $\mathrm{pH}$ controlled and non-controlled experiments. Controlling both $\mathrm{DO}$ and $\mathrm{pH}$ level did not lead to any further improvement of cell growth i.e. the range of growth

'Institute of Biotechnology, Zurich University of Applied Sciences and Facility Management (ZHAW), Wädenswil CH-8820, Switzerland

Full list of author information is available at the end of the article parameter values was the same as that observed in the previous experiments. For High Five cell-based biopharmaceuticals this knowledge enables optimized seed inoculum/seed train production in wave-mixed bag bioreactors.

\section{Author details}

${ }^{1}$ Institute of Biotechnology, Zurich University of Applied Sciences and Facility Management (ZHAW), Wädenswil CH-8820, Switzerland. ${ }^{2}$ Sartorius Stedim Biotech, Göttingen, D-37075, Germany.

Published: 22 November 2011

References

1. Werner S, et al: Innovative, Non-stirred Bioreactors in Scales from Millilitres up to 1000 Liters for Suspension Cultures of Cells using Disposable Bags and Containers - A Swiss Contribution. CHIMIA 2010, 64:819-823.

2. Rhiel M, Mitchell-Logean CM, Murhammer DW: Comparison of Trichoplusia ni BTI-Tn-5B1-4 (High FiveTM) and Spodoptera frugiperda Sf-9 Insect Cell Line Metabolism in Suspension Cultures. Biotechnology and Bioengineering 1997, 55:909-920.

doi:10.1186/1753-6561-5-S8-P123

Cite this article as: Beltrametti et al:: High cell density growth of High Five suspension cells in DO-controlled wave-mixed bioreactors. BMC Proceedings 2011 5(Suppl 8):P123.

Submit your next manuscript to BioMed Central and take full advantage of:

- Convenient online submission

- Thorough peer review

- No space constraints or color figure charges

- Immediate publication on acceptance

- Inclusion in PubMed, CAS, Scopus and Google Scholar

- Research which is freely available for redistribution
C Biomed Central

() 2011 Beltrametti et al; licensee BioMed Central Ltd. This is an open access article distributed under the terms of the Creative Commons Attribution License (http://creativecommons.org/licenses/by/2.0), which permits unrestricted use, distribution, and reproduction in any medium, provided the original work is properly cited. 